\title{
DETERMINANTS OF FIRM VALUE ON CONSUMPTION SECTOR IN INDONESIA
}

\author{
Ji Kyoung Jang \\ Faculty of Busines, University Multimedia Nusantara, Indonesia \\ jangjikyoung@gmail.com \\ Prio Utomo \\ Faculty of Busines, University Multimedia Nusantara, Indonesia \\ prio.utomo@umn.ac.id
}

Received on 11 May 2021

Accepted on 13 June 2021

\begin{abstract}
The purpose of study is to understand the dominan determinants factor which is debt to asset ratio, current ratio, dividend payout ratio and firm size that will influence the firm value in consumer goods companies in Indonesia. To able to maintain dan increase the Indonesia economic growth, Investment and consumption are two main contributor to sustainable economic growth in Indonesia. The study seek for more understanding the determinant that influence the firm value that could support investor decision in consumer goods The study seek for relationship between determinants to predict firm value in the consumption industry which previously done in other sector with inconclusive result. The sample used in this research came from the financial report of 10 of 50 public listed company in IDX between 2013-2017 has high credibility and stability with purposive sampling. The Multiple Regression of modeling are used to analyze the relationship between determinants. The debt to asset ratio, current ratio, and firm size are affect the firm size significantly except for the devident payout ratio, with debt to asset ratio with the most effecting factor. DAR can reflect how financially stable a company is. The higher the ratio, the higher the degree of leverage and, consequently, the higher the risk of investing in that company.
\end{abstract}

Keywords: Firm Size; Consumer Goods; Debt to Asset Ratio; Current Ratio; Firm Size; Dividend Payout Ratio

\section{INTRODUCTION}

\subsection{Research Background}

More than $80 \%$ of Indonesia's economic growth is driven by domestic consumption and investment (BPS, 2020). To maintain economic growth, the government will prioritize these two sectors . Consumption (consumption by households) and business sector investment (Pryanka, 2020). It has an effect on the economy because GDP is the sum of consumer spending, investment, and government spending (exports minus imports). The current role of household consumption will directly affect Indonesia's GDP growth. It is hoped that by increasing household consumption, it will help alleviate the burden on government spending. This occurred as a result of unfavorable external economic conditions, particularly weak public purchasing power, which eighed on household consumption. As the government is heavily reliant on increased public investment and spending, the role of household consumption is 
critical. Increased household consumption will help Indonesia overcome the economic risks it is currently facing. This is critical because it has the potential to boost Indonesia's GDP.

As an indicator for investment in the consumption industry is through the sectoral capitalization reflected in Indonesia Composite Index. According to OJK, the consumption industry has the largest market capitalization in the non-financial sector in 2019, accounting for 16.17 percent of total market capitalization as depicted in Table 1 . The growing consumer goods industry sector has an effect on the manufacturing industry, which is a significant industry due to its size. The consumer goods industry sector is growing because consumer goods are goods that are used on a daily basis (Mantik et al., 2019). The consumer goods industry is a business sector in which raw or semi-finished materials are processed or transformed into finished goods for individual consumption or household consumption in general.

Table 1. The Market Capitalization IDX by Sector

\begin{tabular}{|l|c|}
\hline Sector & Market Capitalization \\
\hline Agricultural & $1.25 \%$ \\
\hline Mining & $4.96 \%$ \\
\hline Basic Industry & $10.79 \%$ \\
\hline Miscellaneous Industry & $5.10 \%$ \\
\hline Consumer Goods & $16.17 \%$ \\
\hline Property and Real Estate & $6.43 \%$ \\
\hline Infrastructure & $10.94 \%$ \\
\hline Financial & $34.95 \%$ \\
\hline Trade & $9.41 \%$ \\
\hline
\end{tabular}

Source: IDX (2020)

The companies in Indonesia need to convince investor to invest in Indonesia. The company's objective is to maximize shareholder value (Miles \& Covin, 2000). Firm Value is what investors consider when determining a company's selling price. The higher the Price Book Value, the more successful a business is at creating value and maximizing shareholder value (Husna \& Satria, 2019). The term Firm Value refers to a ratio that compares the market value of a company's investment to its costs. If the Price Book Value is less than one, the company has failed to create value for its stockholders or shareholders (Ross et al., 2016). There are many previously studies on Firm Value and its determinant with various result and it is never done in the consumption Industry. In previous research, firm value depend on several factors like the profitability, leverage, liquidity, firm size, deviden policy of a firm.

In terms of profitability, the first factor is Return on Assets (ROA), which is the ratio used to calculate profit per dollar of assets (Ross et al., 2016). Firm value can be guaranteed by evaluating the company's ability to generate profits, and ROA has an effect on Firm Value. According Sinaga et al., (2019), ROA has an effect on Firm Value. Sukmawardini \& Ardiansari (2018), on the other hand, discovered that Return on Assets has no effect on Firm Value. For leverage, previous studies uses Debt to Asset Ratio (DAR), which is the ratio of total debts to total assets. This ratio indicates whether the company's assets are sufficient to cover its liabilities when they mature (Sangster \& Wood, 2018). According to Dwipayana \& Suaryana (2016), the Debt to Asset Ratio (DAR) has a significant impact on Firm Value, the same result also that DAR had a positive and statistically significant effect on Firm Value (Michael, 2019), meanwhile in other research the Debt to Asset Ratio (DAR) has no effect on firm value (Husna \& Satria, 2019). In terms of liquidity, the third factor is the Current Ratio (CR), which is the 
liquidity ratio used to determine a company's ability to pay short-term obligations (Reimers, 2014).The CR can be used to determine if short-term assets are sufficient to cover short-term liabilities. (Sangster \& Wood, 2018). Sukmawardini \& Ardiansari (2018) discovered that the CR has a detrimental effect on firm value. According to research conducted by Putra \& Lestari (2016), the CR has a significant positive effect on firm value. Meanwhile, Husna \& Satria (2019) research indicates that the CR has a negligible effect on Firm Value. According to Pratama \& Wiksuana (2016), the fourth factor, Firm Size or company size, refers to a company's total assets. When a company's total assets exceeds a certain threshold, the company is considered mature, has favorable prospects, and is capable of generating profits, as opposed to companies with a small total asset base (Husna \& Satria, 2019). According to Putra \& Lestari,(2016) research, firm size has a positive effect on firm value that have the same result as Sinaga et al. (2019), firm size has a positive and statistically significant effect on firm value. Meanwhile, Haryadi (2016) indicates that the size of the firm has no effect on its value. In terms of dividend policy, the fifth factor is the Dividend Payout Ratio (DPR), which indicates the company's dividend policy. In general, the company's dividends maintain a constant level of income (Marshall et al., 2020). Dividend policy is critical because it demonstrates a company's ability to manage earnings through dividends or retained earnings. Dividends are expected on invested shares. However, if the dividend is high, the company's retained profit will be low, making it difficult to invest. As a result, the company's dividend policy must be properly managed (Husna \& Satria, 2019). According to Putra \& Lestari (2016), the DPR has a positive effect on Firm Value. According to Musabbihan \& Purnawati (2018), the Dividend Payout Ratio (DPR) has a statistically significant positive effect on Firm Value. Meanwhile the DPR has no effect on firm value (Husna \& Satria, 2019; Sukmawardini \& Ardiansari, 2018). Based on previous research and the needs to provide investor on firm value of companies in consumption industry, it is necessary to conduct a research to understand the effect for ROA, DAR, CR, DPR, and Firm Size on Firm Value in consumption industry in Indonesia.

\subsection{Literature Review and Hypotheses \\ 1.2.1 Firm Value}

According to Prihadi \& Manalu (2013), businesses are motivated by a single objective: to prosper shareholders through value creation. The terms par value, book value, intrinsic value, and market value all refer to value. The par value or nominal value of a share in a company in Indonesia is the value that must be owned and is the value that appears on the share sheet. Additionally, shares must maintain their nominal value in order to be legal. The nominal value of a business is ignored when determining its value because it has no economic implications. Book value, or book value, can be found on the lower right side of the balance sheet in the equity account. Book value provides information about the value of a book in the past. Then, through valuation, the intrinsic value of the company can be determined. To distinguish intrinsic value from market value and to indicate that it is the result of valuation, the term intrinsic value was coined. Sellers and buyers in the capital market make transactions based on market value. Market value can be used to determine the potential value that shareholders may realize. Firm Value or firm value is calculated in this study using the Price to Book Value ratio. According to Schmidlin (2014), this ratio is where the premium is stated because the Price to Book Value of most companies is greater than 1, indicating that the market price of the shares is greater than the book value. This is possible if the business continues. 


\subsubsection{Debt to Asset Ratio (DAR)}

This ratio represents the amount of debt compared to the total assets of a company when calculated as a percentage, where: This ratio considers the future of the company, specifically addresses the likelihood of the liabilities being able to pay off the debt of the term. Dividing total assets can calculate the debt to equity ratio by total assets (DAR) or providing room for growth (Sangster \& Wood, 2018).

\subsubsection{Current Ratio (CR)}

The current ratio $(\mathrm{CR})$ is a liquidity ratio that indicates an organization's ability to meet short-term obligations (Reimers, 2014). A high Current Ratio (CR) indicates liquidity, but it can also be interpreted as an inefficient use of cash and other current assets. A healthy Current Ratio (CR) value is one, as anything less than one indicates negative net working capital, which is uncommon in healthy businesses (Ross et al., 2016).

\subsubsection{Firm Size}

According to Pratama \& Wiksuana (2016), firm size or company size refers to a business's total assets. According to Darmayanti \& Mustanda (2016), the following formula is used to determine the size of a business. Understanding the effect of Firm Size on Firm Value becomes very important, so we develop the below hypothesis.

\subsubsection{Dividend Payout Ratio (DPR)}

According to Marshall et al. (2014), the Dividend Payout Ratio (DPR) ratio shows the proportion of profits received as dividends by common stockholders. Based on above description, this study develops hypothesis to understand the relationship between DAR, CR, File Size and DPR with Firm Value by developing below hypothesizes.

H1: Debt to Asset Ratio (DAR) affects Firm Value

H2: Current Ratio (CR) affects Firm Value

H3: Firm Size affects Firm Value

H4: Dividend Payout Ratio (DPR) affects Firm Value

H5: DAR, CR, FS, and DPR affects Firm Value

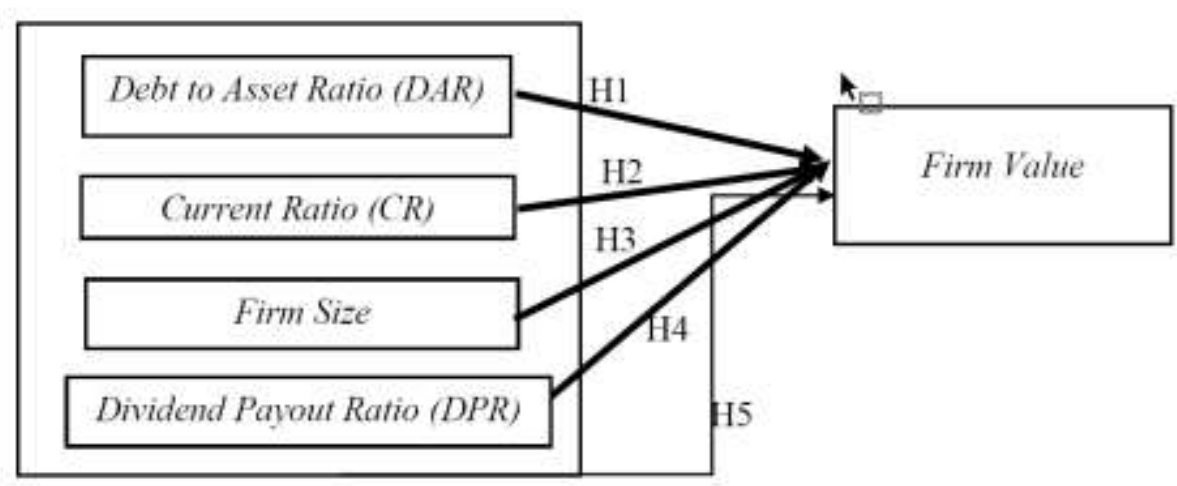

Figure 1. Research Framework 


\section{RESEARCH METHODOLOGY}

This is a inferntial study in which the researcher attempts to comprehend the relationship and influence of one variable on another and the reason for a relationship (Cooper $\&$ Schindler, 2014). The companies in the Consumer Goods Industry listed on the Indonesian Stock Exchange between 2013 and 2017 are the subject of this research. The data is derived from each company's annual financial reports, available on the company's website and through the IDX. Where the sampling company employs purposive/judgmental sampling in accordance with predetermined criteri as depicted in Table 2. From the total thirty-six Consumer Goods companies that listed in the IDX 2013-2017, there are only ten companies that meet the criteria.

Table 2. Sampling Criteria

\begin{tabular}{|l|l|c|}
\hline No & Sample Criteria & $\begin{array}{c}\text { Number of } \\
\text { companies }\end{array}$ \\
\hline 1 & $\begin{array}{l}\text { Consumer Goods company listed in the IDX } \\
\text { between 2013-2017 }\end{array}$ & 36 \\
\hline 2 & $\begin{array}{l}\text { Consumer Goods company listed in the IDX } \\
\text { between 2013-2017 that isseud publicy } \\
\text { audited financial Report between 2013-2017 }\end{array}$ & 35 \\
\hline 3 & $\begin{array}{l}\text { Consumer Goods company with accessable } \\
\text { stock price 2013-2017 }\end{array}$ & 34 \\
\hline 4 & $\begin{array}{l}\text { Consumer Goods company that shared } \\
\text { devident between consequently 2013-2017 }\end{array}$ & 17 \\
\hline 5 & $\begin{array}{l}\text { Consumer Goods company with financial } \\
\text { report in Indonesia Rupiah denominatio } \\
\text { 2013-2017 }\end{array}$ & 17 \\
\hline 6 & $\begin{array}{l}\text { Consumer Goods company that did not } \\
\text { conduct stock split between 2013-2017 }\end{array}$ \\
\hline
\end{tabular}

Source: Authors (2020)

This study will use multiple linear regression analysis to evaluate the below model with descriptive analysis, classical assumption testing, the goodness of fit test, and hypothesis testing.

$$
Y=\alpha+\beta_{1} X_{1}+\beta_{2} X_{2}+\beta_{3} X_{3}+\beta_{4} X_{4}+e
$$

\section{Description}

$\mathrm{Y}=$ Firm Value as dependent variabel

$\alpha=$ constant

$\beta_{1} \beta_{2} \beta_{3} \beta_{4}=$ Independent Variable cooefisien

$X 1=$ Debt to Asset Ratio $(D A R)$

$X_{2}=$ Current Ratio $(\mathrm{CR})$

$X_{3}=$ Firm Size

$X_{4}=$ Dividend Payout Ratio (DPR)

$e=$ Error

According to Ghozali (2013), a descriptive analysis comprises of the average (mean), standard deviation, variance, maximum, minimum, sum, range, kurtosis, and skewness using descriptive statistics (slope distribution). The normality test is performed using the 
Kolmogorov-Smirnov procedure, with the Ho hypothesis stating that the data are normally distributed and the Ha hypothesis stating that the data are not normally distributed. Correlation between independent variables in a regression model is determined using the multicollinearity test. If there is no correlation between the independent variables, the regression model is considered to be good. Three indicators indicate the presence of multicollinearity. First, the R2 value indicates that the regression model estimate is very high but not statistically significant, indicating the effect of numerous independent variables on the dependent variable. Second, the correlation matrix of the independent variables is analyzed to determine whether there is multicollinearity if the correlation between the independent variables is sufficiently high. Third, it is possible to determine the extent to which each independent variable is explained by other independent variables using the tolerance value and variance inflation factor (VIF). In general, multicollinearity indicates that the Tolerance value is less than or equal to 0.10 or that the VIF value is greater than or equal to 10 . Third, the autocorrelation test is used to determine whether there is a correlation between the confounding error period $t$ and $t-1$. The Durbin Watson Test is one method for determining autocorrelation. The Durbin Watson test is only applicable to level one autocorrelation and indicates that the regression model's intercept (constant) is constant and that there is no lag variable between the independent variables.

The following hypotheses can be tested: Ho: there is no autocorrelation $(r=0)$ and Ha: there is no autocorrelation ( $\mathrm{r} 0$ ). Fourth, the heteroscedasticity test is used to determine whether there is a variance inequality between the residuals of one observation and those of another. If the variance is constant, it is called homoscedasticity; if the variance is different, it is called heteroscedasticity. Heteroscedasticity is detected by comparing the predictive value of the dependent variable, ZPRED, to the residual SRESID. Heteroscedasticity is illustrated in the scatterplot graph, where the $\mathrm{Y}$-axis represents the predicted $\mathrm{Y}$, and the $\mathrm{X}$-axis represents the residual. The analysis is based on the observation that heteroscedasticity occurs when a particular pattern is formed, such as a regular pattern. If there is no discernible pattern and the dots are scattered at the top and bottom of the number 0 on the $\mathrm{Y}$ axis, heteroscedasticity does not exist.

The goodness of fit test determines how precisely the related sample regression function determines the actual value. The coefficient of determination $\left(\mathrm{R}^{2}\right)$ indicates the model's ability to explain variation in the dependent variable. The coefficient of determination is between 0 and 1 . If R2 is negligible, it can be concluded that the independent variables' ability to explain the dependent variables is also quite limited. However, if $\mathrm{R}^{2}$ is close to 1 , the independent variables can provide sufficient information to predict the variation in the dependent variable. The disadvantage of the coefficient of determination is that it produces an erroneous estimate of the number of independent variables in the model. $\mathrm{R}^{2}$ will increase whenever one independent variable is added, regardless of whether these variables significantly affect the dependent variable. Adjusted $\mathrm{R}^{2}$ is preferred for evaluating the regression model because it can increase or decrease with the addition of a single independent variable.

There is a significant simultaneous test ( $F$ statistical test) and a significant test for individual parameters in the hypothesis test ( $\mathrm{t}$ statistical test). The F statistical test can be used to determine whether all independent variables have a cumulative effect on the dependent variable. Ho: $\mathrm{b} 1=\mathrm{b} 2=\ldots=\mathrm{bk}=0$ and Ha: $\mathrm{b} 1 \mathrm{~b} 2 \ldots \mathrm{bk} 0$ are the hypotheses to be tested. If the significance level of the $\mathrm{F}$ test results is less than 0.05 , Ho is rejected, indicating that all independent variables affect the dependent variable. In contrast, if the $F$ test result is greater than 0.05 , Ho is accepted to ensure that all independent variables do not influence the dependent variable concurrently. The t statistical test can be used to determine the extent to which each independent variable contributes to explaining variation in the dependent variable. 
Ho: bi $=0$ and Ha: bi 0 are the hypotheses to be tested. If the significance value of the t-test results is less than 0.05 in this study, Ho is rejected, indicating that the independent variable affects the dependent variable. However, if the significant value of the t-test is greater than 0.05 , Ho is accepted, indicating that the independent variable does not affect the dependent variable.

\section{RESULTS AND DISCUSSION}

\subsection{Descriptive Analysis}

Analying the Firm Value, as depicted in Table 3, the lowest value of Firm Value is 0.7184 and the highest value is Firm Value which is 16.4889 . The average Firm Value is 4.1131 with a standard deviation of 3.4159. The lowest Firm Value as measured by the Price Book Value is 0.7184 which is the value of PT Sekar Laut Tbk in 2016. This is due to the 2016 stock price decreased slightly compared to 2015 , from $\mathrm{Rp}$. 370 to $\mathrm{Rp}$. 308 , while total equity experienced a high increase, from Rp. 152.04 billion to Rp. 296.15 billion. The highest value of Firm Value, namely 16.4889 is the Firm Value of PT Unilever Indonesia Tbk in 2017. This is due to an increase in share prices of $44.07 \%$, from IDR 7,760 in 2016 to IDR 11,180 while the increase in total equity is only $9.9 \%$ i.e. from $\mathrm{Rp} 4.7$ trillion to $\mathrm{Rp} 5.1$ trillion.

The average value in Table 3 shows that investors paid an average of 4.1131 times the book value of the sample firms. By knowing that the standard deviation of 3,4159 is a value below the average of 4.1131 , it can be concluded that the data variable distribution of the Firm Value is small, which means that there is no gap that is far from the smallest value to the largest value.

The independent variables used in this study are Return on Assets (ROA), Debt to Asset Ratio (DAR), Current Ratio (CR), Firm Size, and Dividend Payout Ratio (DPR). The results of the descriptive statistical analysis of the independent variables are as follows. Descriptive statistical analysis shows that the first independent variable, namely Return on Assets (ROA), has the lowest value, namely $2.96 \%$; the highest value is $42.14 \%$; the average is $12.08 \%$ and the standard deviation is $10.05 \%$. The lowest value is the value owned by PT Nippon Indosari Corpindo Tbk in 2017. This is because when compared to 2016, net profit decreased by $51.62 \%$ from IDR 279.77 billion to IDR 135.36 billion while total assets increased by $56.17 \%$ from Rp 2.91 trillion to $\mathrm{Rp} 4.56$ trillion. The highest value on Return on Assets (ROA) was owned by PT Unilever Indonesia Tbk in 2013. This is because the net profit of PT Unilever Indonesia Tbk was IDR 5.35 trillion in 2013 with total assets of IDR 12.7 trillion. The net profit is equivalent to the range of PT Gudang Garam Tbk's net income, while the total assets are much smaller than the total assets of PT Gudang Garam Tbk.

The average value of Return on Assets (ROA) in Table 3 shows that the average sample company can generate net income of $12.08 \%$ of the company's total assets. By knowing that the standard deviation is $10.05 \%$ is a value that is below the average value of $12.08 \%$, it can be concluded that the distribution of the data variable from Return on Assets (ROA) is small, which means that there is no gap that is far from the smallest value with the largest value.

For the second independent variable, namely Debt to Asset Ratio (DAR), it has the lowest value, namely 0.1638 ; the highest value is 0.7264 ; the average is 0.4121 and the standard deviation is 0.1609 . The lowest value is the value owned by PT Kalbe Farma Tbk in 2017. This is because the total liabilities owned by the company in 2013-2017 are in the range of IDR 2 trillion respectively while total assets have increased by around IDR 1 trillion in 2013-2017 each. The year. The highest value of Debt to Asset Ratio (DAR) was owned by PT Unilever Indonesia Tbk in 2017 where the range of Debt to Asset Ratio (DAR) in 2013-2017 was in the range of $60 \%-70 \%$. 
The variable Debt to Asset Ratio (DAR) shows that the average sample of companies has total liabilities of 0.4121 of the company's total assets. This means that, on average, a sample of companies can pay total liabilities using total assets. By knowing that the standard deviation of 0.1609 is a value that is below the average value of 0.4121 , it can be concluded that the distribution of the data variables is small, which means that there is no gap that is far from the smallest value to the largest value.

Analyzing the Current Ratio (CR), has the lowest value, namely 0.6056; the highest value is 5.3245; the average is 2.3487 and the standard deviation is 1.2497 . The lowest value is the value that came from PT Unilever Indonesia Tbk in 2016. This is because in the sample company, only PT Unilever Indonesia Tbk owned it in 2013-2017. Current Ratio (CR) value is below the value of 1 for each year where total current assets are less than total short-term total liabilities

The highest value of Current Ratio (CR) was owned by PT Mandom Indonesia Tbk in 2016. This can happen because in 2016 there was an increase in current assets originating from cash and cash equivalents as well as insurance claims for fires. However, short-term liabilities are much lower than in 2014 because in 2015 bank debt was paid of Rp. 186 billion.

The variable Current Ratio (CR) shows that the average sample of companies has current assets of 2.3487 times of short-term liabilities. This means that, on average, a sample of companies is able to pay short-term liabilities using current assets. By knowing that the standard deviation of 1.2497 is a value below the average of 2.3487 , it can be concluded that the distribution of the data variable is small, which means that there is no gap that is far from the smallest value with the largest value.

On Firm Size, the lowest value is 25.0771; the highest score was 31.8321; the average is 28.7581 and the standard deviation is 1.4189 . The lowest value is the value that came from PT Indofood Sukses Makmur Tbk in 2013. This is because PT Indofood Sukses Makmur Tbk has the smallest total assets, namely in 2013, which was IDR 77.78 billion when compared to other samples. Meanwhile, the highest value was owned by PT Gudang Garam Tbk in 2017. The highest value of Firm Size was due to the total assets owned by PT Gudang Garam Tbk in 2017

Table 3. Descriptive Analysis

\begin{tabular}{|l|c|c|c|c|c|}
\hline & $\mathrm{N}$ & Minimum & Maximum & Mean & Std. Deviation \\
\hline Firm Value & 50 & 0,718376062 & $1,648,888,504$ & $4,113,121,102$ & $3,415,891,141$ \\
\hline Return on Assets & 50 & 0,0296878677 & 0,4213514766 & 0,1207741073 & 0,1005475189 \\
\hline Debt to Asset Ratio & 50 & 0,1638281422 & 0,7263686137 & 0,4121334112 & 0,1608534982 \\
\hline Current Ratio & 50 & 0,6056319345 & $5,324,509,743$ & $2,348,741,703$ & $1,249,725,941$ \\
\hline Firm Size & 50 & $2,507,712,368$ & $3,183,212,417$ & $2,875,819,734$ & $1,814,975,183$ \\
\hline $\begin{array}{l}\text { Dividend Payout } \\
\text { Ratio }\end{array}$ & 50 & 0,0999359385 & 0,9895561358 & 0,4415230127 & 0,2337442462 \\
\hline
\end{tabular}

Source: Authors (2020)

Based on the analysis, Dividend Payout Ratio (DPR), has the lowest value, namely 0.0999 ; the highest value is 0.9896 ; the average is 0.4415 and the standard deviation is 0.2337 . The lowest value is the value owned by PT Nippon Indosari Corpindo Tbk in 2013.This is because compared to samples from other companies, the Dividend Payout Ratio (DPR) from PT Nippon Indosari Corpindo Tbk in 2013-2017 is in the range of only $10 \%-25 \%$. . Meanwhile, the highest value was owned by PT Unilever Indonesia Tbk in 2015 where the company's Dividend Payout Ratio (DPR) was in the range of $90 \%$ (the highest from a sample 
of other companies) in 2013-2017. The Dividend Payout Ratio (DPR) variable in Table 3 shows that the average dividend distribution in the sample companies is 0.4415 of earnings per share. By knowing that the standard deviation of 0.2337 is a value below the average value of 0.4415 , it can be concluded that the distribution of the data variables is small, which means that there is no gap that is far from the smallest value with the largest value.

\subsection{Parameter Signifiicant Test (t-test)}

The $t$ statistical test can test the extent to which the influence of one independent variable individually in explaining the variation in the dependent variable.

Table 4. Statistical t-test Result

\begin{tabular}{|c|c|c|c|}
\hline Model & Standardized Coefficients Beta & t & Sig. \\
\hline (Constant) & & $-5,143$ & 0,000 \\
\hline Debt to Asset Ratio & 0,998 & 3,908 & 0,000 \\
\hline SqrtCR & 0,568 & 2,246 & 0,030 \\
\hline Firm Size & 0,644 & 6,233 & 0,000 \\
\hline SqrtDPR & 0,134 & 1,343 & 0,186 \\
\hline
\end{tabular}

Source: Author (2020)

The following is a regression model that can be arranged by referring to the $\mathrm{t}$ test results table in Table 4:

\section{Firm Value $=0.998$ DAR + 0.568 CR + 0.644 SIZE + 0.134 DPR + e}

The significance value of the Debt to Asset Ratio (DAR) is 0,000. This value is below the significance value of 0.05 . Therefore, it can be concluded that the Debt to Asset Ratio (DAR) has a positive effect on Firm Value. The results of this study are also supported by research by Dwipayana \& Suaryana (2016) where the Debt to Asset Ratio has a significant effect on Firm Value. Ardana (2018) and Michael (2019) found that the Debt to Asset Ratio had a positive and significant effect on Firm Value. There is a signal theory where there are signals from companies on the market that can provide information on the quality of the company. The assets and capital of the company can be seen from the company's debt where the high Debt to Asset Ratio means that the amount of capital used for investment is also high (Dwipayana \& Suaryana, 2016). The choice of funding sources has an influence on the financial structure of the company which will also have an impact on the value of the company. This means it is important for companies to be careful in determining the right source of funding (Michael, 2019). However, the results found in this study are not in line with the research of Husna \& Satria, (2019) which states that the Debt to Asset Ratio has no effect on Firm Value. Research by

Lebo \& Tasik (2017) suggests that the Debt to Asset Ratio has no effect on Firm Value. This is because there are differences in industry and research period, namely where Husna \& Satria (2019) was conducted in the manufacturing industry in 2013-2016 and Lebo \& Tasik (2017) was carried out in the automotive and components sub-sector in 2007-2016 while this research was conducted on consumer goods industry in 2013-2017.

The significance value of the $t$ test on the Current ratio is 0.030 . This value is below the significance value of 0.05 . This can be interpreted as Current Ratio (CR) has a positive effect on Firm Value. The results of this study are also in line with research from Putra \& Lestari (2016) which states that the Current Ratio has a significant positive effect on Firm Value. This can be due to the increase in company value following increased liquidity. In addition, this is 
because it is considered a company that has good liquidity because of the high Current Ratio. The value of the Current Ratio owned by 9 out of 10 companies is above 1 in the 2013-2017 sample. This shows that the majority of companies in the sample have good liquidity (Ross et al., 2016). In addition, research by Sukmawardini \& Ardiansari (2018) states that the Current Ratio has a negative effect on Firm Value because a high Current Ratio can be seen as a condition in which cash assets are not optimally used, thereby reducing firm value. Akbar \& Fahmi (2020) states that the Current Ratio has a significant negative effect on Firm Value where liquidity causes company value to decrease. This can be caused by uncollectible accounts or inventories that have not been sold so that liquidity is high. Meanwhile, Husna \& Satria (2019)suggests that the Current Ratio does not have a significant effect on Firm Value where the Current Ratio does not describe the Price Book Value. This can be caused when investing, the Current Ratio is not paid attention by investors because it only describes the company's ability to pay short-term liabilities using current assets. According to Kushartono \& Nurhasanah (2018), Current Ratio has a negative but insignificant effect on Firm Value. The difference in research results is due to differences, namely Husna \& Satria (2019) research was conducted in the manufacturing industry in 2013-2016 and Kushartono \& Nurhasanah (2018) was conducted on the LQ45 Index in 2010-2016.

The significance value of Firm Size has a value of 0,000 where the value is below the significance level of 0.05 . This shows that Firm Size has a positive influence on Firm Value. The results of this study are supported by Putra \& Lestari (2016) which found that Firm Size has a positive influence on Firm Value. Research by Sinaga et al. (2019)also states that Firm Size has a significant positive effect on Firm Value. Prastuti \& Sudiartha (2016) found that Firm Size has a negative effect on Firm Value. The size of the company can have an influence on company value. The advantage will be owned by a company with a large size because it makes it easier to penetrate the capital market so that it is possible to obtain additional funds. Investors can assess this as potential so that investors are interested in investing. The value of the company will increase if the total assets increase (Putra \& Lestari, 2016).

The significance value of the Dividend Payout Ratio (DPR) is 0.186. This value is above the significance value of 0.05 This shows that the Dividend Payout Ratio (DPR) has no effect on Firm Value. The results of this study are supported by research by Husna \& Satria (2019) in major, where it was found that the Dividend Payout Ratio (DPR) had no effect on Firm Value. It does not affect the two variables, namely because investors do not care about the return obtained whether it comes from capital gains or dividends and the determination of profits to be distributed into dividends or used as retained earnings does not have an effect on company value (Husna \& Satria, 2019). However, the results of this study are not supported by research by Putra \& Lestari (2016) which found that the Dividend Payout Ratio (DPR) has a positive effect on Firm Value. According to the results obtained from the research of Musabbihan \& Purnawati (2018), the Dividend Payout Ratio (DPR) has a significant positive effect on Firm Value. Research by Prastuti \& Sudiartha (2016) suggests that the dividend policy as measured by the Dividend Payout Ratio (DPR) has a significant positive effect.This difference is due to differences in period and industry. Putra \& Lestari (2016) was conducted in the manufacturing industry in 2010-2013. Musabbihan \& Purnawati (2018) was conducted on the property \& real estate industry in 2012-2016.

\section{CONCLUSION, LIMITATION AND SUGGESTIONS 4.1 Conclusion}

Based on the results of the analysis and discussion in previous section, the following conclusions can be drawn: DAR, CR, Firm Size, and DPR simultaneously affect Firm Value. 
And all of the the respective variabel have the positive and significant relationship with Firm Value except for DPR with insignificant relationship with the Firm Value. Debt to Asset Ratio becomes that largest effect to the firm value. DAR can reflect how financially stable a company is. The higher the ratio, the higher the degree of leverage (DoL) and, consequently, the higher the risk of investing in that company.

\subsection{Limitation}

The limitation of this research are on the sector of analysis which is focus only on the consumer goods industry that conducted on the financial performance between 2013-2017 that happen before COVID-19. Further research in other sector with recent timeline with comparison after the COVID-19 pandemic would be an interesting topic.

\subsection{Suggestions}

Based on the research results, the following suggestions can be given.(1) Should consider Debt to Asset Ratio (DAR), Current Ratio (CR), Firm Size, and Dividend Payout Ratio (DPR) if simultaneously in assessing the feasibility of a company in creating Firm Value. This is because the four independent variables simultaneously have an effect on Firm Value.(2) Efforts to increase the Debt to Asset Ratio (DAR) should be prioritized if partially the efforts to increase Firm Value. This is because the Debt to Asset Ratio (DAR) has a positive effect on Firm Value. Because of this influence, it is advisable to be careful in determining the level of funding sources. (3) It is recommended for those who have a goal to create Firm Value, to pay attention to the Current Ratio (CR) if it is partially valued at 1 or close to 1 . This is because Current Ratio (CR) has a positive effect on Firm Value.(4) It is recommended to prefer companies with large sizes compared to small companies because they are easier to enter the capital market so that it is easier to increase Firm Value. This is because Firm Size has a positive effect on Firm Value.(5) It would be better if you prioritize Firm Value, then don't give priority to Dividend Payout Ratio (DPR) if partially because investors do not prioritize sources of return, namely dividends or capital gains so that it does not affect Firm Value.

\section{REFERENCES}

Akbar, F., \& Fahmi, I. (2020). Pengaruh Ukuran Perusahaan, Profitabilitas dan Likuiditas Terhadap Kebijakan Dividen dan Nilai Perusahaan pada Perusahaan Manufaktur yang Terdaftar di Bursa Efek Indonesia. Jurnal Ilmiah Mahasiswa Ekonomi Manajemen, 5(1), 7. https://doi.org/10.46821/ekobis.v1i1.1

Ardana, Y. (2018). Kinerja Keuangan dan Nilai Perusahaan : Analisis Data Panel pada Jakarta Islamic Index. Jurnal Masharif Al-Syariah: Jurnal Ekonomi Dan Perbankan Syariah, 3(2). https://doi.org/10.30651/jms.v3i2.1765

BPS. (2020). [Seri 2010] PDB menurut Pengeluaran (Milyar Rupiah), 2020. Badan Pusat Statistik. https://www.bps.go.id/indicator/169/107/1/-seri-2010-pdb-menurutpengeluaran.html

Cooper, D. R., \& Schindler, P. S. (2014). Business Research Methods. McGraw-Hill/Irwin.

Darmayanti, N. K. D., \& Mustanda, I. K. (2016). Pengaruh Pertumbuhan Penjualan, Jaminan Aset, dan Ukuran Perusahaan Terhadap Kebijakan Deviden pada Sektor Industri Barang Konsumsi. E-Jurnal Manajemen, https://ojs.unud.ac.id/index.php/Manajemen/article/view/20369

Dwipayana, M., \& Suaryana, I. G. N. (2016). Pengaruh Debt To Assets Ratio, Deviden Payout Ratio, and Return on Assets Terhadap Nilai Perusahaan. E-Jurnal Akuntansi, 17(3), 2008- 
2035. https://ojs.unud.ac.id/index.php/Akuntansi/article/view/22313

Ghozali, I. (2013). Aplikasi Analisis Multivariate Dengan Program IBM SPSS 21 Update PLS Regresi.

Haryadi, E. (2016). Pengaruh Sizeperusahaan, Keputusan Pendanaan, Profitabilitas dan Keputusan Investasi terhadap Nilai Perusahaan. Jurnal Akuntasi Vol. 3 No. 2 Juli 2016, $3(2)$, 84-100.

https://e-

jurnal.lppmunsera.org/index.php/Akuntansi/article/download/211/272/

Husna, A., \& Satria, I. (2019). Effects of Return on Asset, Debt To Asset Ratio, Current Ratio, Firm Size, and Dividend Payout Ratio on Firm Value. International Journal of Economics and Financial Issues, 9(5), 50-54. https://doi.org/10.32479/ijefi.8595

IDX. (2020). Daftar Saham Per Sektor. Indonesia Stock Exchange. https://www.idx.co.id/produk/saham/\#Klasifikasi Sektor dan Subsektor

Kushartono, R. C., \& Nurhasanah, N. (2018). Analisis Pengaruh Rasio Keuangan Terhadap Nilai Perusahaan Pada Perusahaan Yang Tergabung Dalam Indeks Lq45 Periode 2010 2016. Buana Ilmu, 2(1), 108-125. https://doi.org/10.36805/bi.v2i1.278

Lebo, T. C., \& Tasik, H. H. D. (2017). the Impact of Financial Ratios on Price To Book Value (Pbv) in Automotive and Component Sub Sector Listed in Idx Within 2007-2016 Periods. Jurnal EMBA: Jurnal Riset Ekonomi, Manajemen, Bisnis Dan Akuntansi, 5(3). https://doi.org/10.35794/emba.v5i3.17463

Mantik, M. Q. H. M., Tampi, D. L., \& Manoppo, W. S. (2019). Pengaruh Earning Per Share Terhadap Harga Saham Perusahaan Manufaktur Sektor Barang Konsumsi yang Terdaftar Di Bursa Efek Indonesia Periode 2015-2018. Jurnal Administrasi Bisnis, 9(2), 1. https://doi.org/10.35797/jab.9.2.2019.23895.1-8

Marshall, D. H., McManus, W. W., \& Viele, D. F. (2020). Accounting : what the numbers mean. McGraw-Hill Education.

Michael, H. R. (2019). The Effect Of Financial Ratio On Company Value With Inflation As A Moderation Variable. Jurnal Akuntansi, 23(1), 33. https://doi.org/10.24912/ja.v23i1.458

Miles, M. P., \& Covin, J. G. (2000). Environmental Marketing: A Source of Reputational, Competitive, and Financial Advantage. Journal of Business Ethics, 23(3), 299-311. https://doi.org/10.1023/A:1006214509281

Musabbihan, N. A., \& Purnawati, N. K. (2018). Pengaruh Profitability dan Kebijakan Deviden Terhadap Nilai Perusahaan dengan Struktur Modal sebagai Pemediasi. E-Jurnal Manajemen, 7(4). https://ojs.unud.ac.id/index.php/Manajemen/article/view/36849

Prastuti, N. K. R., \& Sudiartha, I. G. M. (2016). Pengaruh Struktur Modal, Kebijakan Dividen, dan Ukuran Perusahaan terhadap Nilai Perusahaan pada Perusahaan Manufaktur. EJurnal Manajemen, 5(3). https://ojs.unud.ac.id/index.php/Manajemen/article/view/16540

Pratama, I. G. B. A., \& Wiksuana, I. G. B. (2016). Pengaruh Ukuran Perusaan dan Leveraeg Terhadap Nilai Perusahaan dengan Profitability Sebagai Variabel Mediasi. E-Jurnal $\begin{array}{llllll}\text { Manajemen; } & \text { Vol } & 5 & \text { No } & 2 & \text { (2016). }\end{array}$ https://ojs.unud.ac.id/index.php/Manajemen/article/view/17498

Prihadi, T., \& Manalu, S. F. (2013). Analisis Laporan Keuangan Lanjutan: Proyeksi \& Valuasi. PPM.

Pryanka, A. (2020). Konsumsi dan Investasi, Kunci Ekonomi Bisa Tumbuh Tahun Ini. Repubika. https://www.republika.co.id/berita/qflw96370/konsumsi-dan-investasi-kunciekonomi-bisa-tumbuh-tahun-ini 
Putra, A. A. N. A., \& Lestari, P. (2016). Pengaruh Kebijakan Dividen, Likuiditas, Profitabilitas dan Ukuran Perusanaan terhadap Nilai Perusahaan. E-Jurnal Manajemen, 5(7). https://ojs.unud.ac.id/index.php/Manajemen/article/view/20373

Reimers, J. L. (2014). Financial Accounting: a Business Process Approach. Pearson Education Ltd.

Ross, S. A., Westerfield, R., \& Jordan, B. D. (2016). Fundamentals of Corporate Finance. McGraw Hill Education.

Sangster, A., \& Wood, F. (2018). Frank Wood's Business Accounting Volume 2. Pearson Education Limited.

Schmidlin, N. (2014). Art of company valuation and financial statement analysis : a value investor's guide with real-life case studies. Wiley. https://www.dawsonera.com.ezproxy.buid.ac.ae/abstract/9781118843048

Sinaga, L., Nababan, A., Sinaga, A., Hutahean, T., \& Guci, S. (2019). Pengaruh Sales Growth, Firm Size, Debt Policy, Return On Asset terhadap Nilai Perusahaan pada Perusahaan Property dan Real Estate yang Terdaftar di Bursa Efek Indonesia. Journal of Economic, Bussines and Accounting (COSTING), 2, 345-355. https://doi.org/10.31539/costing.v2i2.664

Sukmawardini, D., \& Ardiansari, A. (2018). The Influence of Intitutional Ownership, Profitability, Liquidity, Dividend Policy, Debt Policy on Firm Value. Management Analysis Journal, 7(2), 211-222. 